\title{
THE ROLE OF SOCIALLY RESPONSIBLE MARKETING IN THE REPRODUCTION OF THE HUMAN CAPITAL AND REDUCTION OF ITS FIKTIVIZATION PROCESSES
}

\author{
Olena Brintseva ${ }^{1}$ \\ Kyiv National Economic University named after Vadym Hetman, Ukraine \\ Oksana Hutsalenko² \\ Vinnytsia National Agrarian University, Ukraine \\ Sergii Dmitruk ${ }^{3}$ \\ Kyiv National Economic University named after Vadym Hetman, Ukraine
}

\begin{abstract}
The urgency of the research. Before the modern person at different stages of reproduction of the human capital, there are many calls and risks that need to be considered and also to adapt to consequences of their action. Target setting. Use of marketing tools is rather a perspective direction of improvement of processes of the human capital reproduction. However, improvement of these processes is promoted by only socially responsible marketing. Uninvestigated parts of general matters defining. Almost unexplored are questions of use of marketing tools in the realization of processes of reproduction of the human capital. The purpose of the paper is to study the use of marketing tools for more effective implementation of reproduction processes of human capital at different stages. The issue of reproduction of human capital is considered in such areas: education, health, and social and labour sphere. Methodology. The paper is based on a critical analysis of scientific researches in the sphere of socially responsible marketing and processes of reproduction of human capital. These issues are researched by Blagov Yu.E., Carroll A., Hrishnova O.A., Kotler P., Lantos J., Lambin J., Libanova E.M., Mishchuk H.Yu., and others. Results. Issues of the human capital reproduction are considered in the following spheres: education, healthcare, and social and labour sphere. It is defined that in modern conditions, social responsibility has to become a basis for the creation of all system of the public relations and cover all stages of reproduction of the human capital. Socially irresponsible marketing leads to the formation, accumulation, and distribution of the fictitious human capital and other its unproductive forms. Practical implications. Now reproduction of the human capital in Ukraine is rather strongly influenced by fiktivization processes connected with the distribution of its unproductive forms. In this context, socially irresponsible marketing of educational and medical institutions, enterprises-employers, pharmaceutical and intermediary firms, plays a considerable role. Socially responsible marketing is impossible without the general spread of the ideology of social responsibility in society. The concept of social responsibility should become widespread in all spheres of public life, should become a fundamental basis of social and labour relations and one of the most important directions for overcoming a systemic socio-economic, political, and military crisis in Ukraine.
\end{abstract}

Key words: socially responsible marketing, fictitious human capital, human capital reproduction, education, health, social and labour issues.

JEL Classification: M14, M31, 015

\section{Introduction}

Now processes of reproduction of the human capital happen in rather difficult conditions - reforming of an education system and healthcare, multi-vector changes in the social and labour sphere, changes in the content of labour and its forms related to the development of information and communication technologies, strong influence of system social and economic, political, military crisis. Before the modern person at different

\footnotetext{
Corresponding author:

${ }^{1}$ Department of Personnel Management and Labour Economics, Kyiv National Economic University named after Vadym Hetman.

E-mail: o.brintseva@gmail.com

${ }^{2}$ Department of Finance, Banking and Insurance, Vinnytsia National Agrarian University.

E-mail: 557555@ukr.net

${ }^{3}$ Department of Personnel Management and Labour Economics, Kyiv National Economic University named after Vadym Hetman.

E-mail: sergei-dmitruk@ukr.net
} 
stages of formation of labour potential, development, use, and saving of the human capital, there are many calls and risks which need to be considered and also to adapt to consequences of their action. In such conditions, the research of questions of management of reproduction of the human capital at all stages acquires special relevance, increase in the efficiency of processes connected with it is the key to restoration of socially oriented economic growth, expansion of opportunities of productive employment, ensuring the welfare of the population. The use of marketing tools is rather a perspective direction of improvement of processes of reproduction of the human capital. However, only socially responsible marketing helps to improve these processes. Marketing, which does not have such a characteristic, provokes and propagates the processes of human capital fiktivization.

Various aspects of socially responsible marketing are researched by Blagov Yu.E., Carroll A., Kotler P., Lantos J., Lambin J. and others; processes of reproduction of human capital - by Hrishnova O.A., Libanova E.M., Mishchuk H.Yu., etc. But almost unexplored are questions of the use of marketing tools in the realization of processes of reproduction of the human capital in various spheres of labour potential/human capital formation, its development, use, and preservation.

The purpose of the article is to study the use of marketing tools for more effective implementation of the reproduction processes of human capital at different stages, prevention of its fiktivization. The issue of reproduction of human capital is considered in such areas: education, health, and social and labour spheres. The emphasis is made on the social responsibility of marketing activities at all levels and in all areas of this process.

\section{Social responsibility of marketing}

Development of the concept of socially responsible marketing has begun rather recently - in the third quarter of the XX century. Classical definition of socially responsible marketing at microeconomic level was offered by P. Kotler (Kotler, 1972, 2008) who, in particular, notes that the concept of socially responsible marketing proclaims a task of the enterprise establishment of requirements, desires, and interests of target markets and their satisfaction more effective and productive than at competitors in the ways, which keep or increase welfare of both the consumer, and society in general. Thus, socially responsible marketing is considered as an essential competitive advantage of the enterprise. At the same time, it is an effective remedy for social development.

Socially responsible marketing is a process of identification and satisfaction of needs of consumers taking into account their real, healthy interests, and also needs of nature of all society, its sustainable development. Socially responsible marketing can't stimulate consumption of harmful production or induce consumers to spend money for services that will not benefit either themselves or society.

At the micro level, socially responsible marketing is also considered as a voluntary activity of business structures for the solution of social problems, assistance to the population, territories and, on the one hand, based on decision-making, proceeding from the common humanitarian goals and values of society, and with another - considering objective need of business to be socially responsible, including through active realization and updating of the activity among the population, strengthening its business and social reputation (Agramakova, 2011).

Consideration and satisfaction of social needs is an important prerequisite for the effective marketing activity of any modern enterprise, but especially - state authorities, educational and medical institutions, public organizations. This also applies to people as participants in social and labour relations. It is quite promising to apply socially responsible marketing at the individual level to ensure the processes of reproduction of human capital. In the twenty-first century, when the information is spreading very easily and quickly, social responsibility in marketing activities is of particular importance since any false information, on the one hand, spreads quickly and can bring significant harm to society and, on the other hand, it can be detected rather quickly and lead to significant financial losses.

\section{The concept of the fictitious human capital}

In modern conditions, social responsibility has to become the uniting national idea, a basis for the creation of all system of the public relations, their dominant, and to cover all aspects of the formation of labour potential, development, use, and saving of the human capital. Socially irresponsible marketing leads to the formation, accumulation, and distribution of the fictitious human capital and other its unproductive forms.

We define a fictitious human capital as a result of unproductive and unlawful investments (or deformed as a result of prolonged non-use) of a person's current and accumulated stock of fictitious characteristics of health, knowledge, skills, abilities that this person is purposefully employed in social and labour relations, not contributes to the growth of labour productivity, but it affects the growth of income of its owner, reducing the possible profits of the enterprise and national income (Hrishnova \& Brintseva, 2015). Fictitious human capital is formed primarily in the field of education and vocational training, healthcare, social and labour sphere. The isolation of these areas as the main characteristics of the processes of human capitalization is due primarily to the fact that in these areas, processes of human capital formation, accumulation, and use are the most dynamically taking place. 


\section{The role of socially responsible marketing in processes of human capital reproduction}

Depending on the sphere of reproduction of human capital, one can distinguish the following directions for using marketing tools (Table 1 ).

Formation of labour potential/human capital in the educational sphere requires significant investments, much of which is done by domestic households and individuals. A promising direction for diversifying funding sources is the search for grants for training, internships, participation in various educational events funded by international organizations. The following marketing tools help to increase the efficiency of these processes: self-presentation and self-promotion during participation in various educational events, preparation of qualitative applications for grants, scientific projects. To prevent further fiktivization and the formation of unproductive forms of human capital, the acquisition of fictitious documents about education, marketing at all levels must be virtuous, socially responsible. This applies not only to self-marketing but also to the marketing of educational institutions and various types of educational services because often enough the formation of fictitious capital is promoted not only by the demand for low-quality education but also by the availability of educational institutions that provide such services.

Within the framework of expanding cooperation between educational institutions and business, the formation of professional competencies for future employees is a promising direction in the development of dual education, that is, the combination of theoretical training in an educational institution and practical - at the enterprise. This gives an opportunity to take full account of special requirements of the workplace to the characteristics of the employee and to form them, as well as to select the most suitable workplace for the person. The social responsibility of marketing in these

Table 1

The role of socially responsible marketing in processes of human capital reproduction

\begin{tabular}{|c|c|c|c|}
\hline \multirow{2}{*}{$\begin{array}{l}\text { Stages and areas of } \\
\text { reproduction of human } \\
\text { capital }\end{array}$} & Sphere of education & Sphere of healthcare & Social and labour sphere \\
\hline & \multicolumn{3}{|c|}{ use of marketing tools for: } \\
\hline $\begin{array}{l}\text { Formation of labour } \\
\text { potential / human capital }\end{array}$ & $\begin{array}{l}\text { - investments for the formation of } \\
\text { human capital/labour potential from the } \\
\text { state and international organizations; } \\
\text { - effective self-presentation and self- } \\
\text { promotion during participation in } \\
\text { various educational events; } \\
\text { - responsible marketing of educational } \\
\text { institutions; } \\
\text { - development of the system of higher } \\
\text { education in Ukraine, ensuring a wider } \\
\text { representation of domestic higher } \\
\text { education institutions in international } \\
\text { rankings, etc. }\end{array}$ & $\begin{array}{l}\text { - investments for the } \\
\text { formation of human capital/ } \\
\text { labour potential from the } \\
\text { state and international } \\
\text { organizations; } \\
\text { - approval of health- } \\
\text { conservation values; } \\
\text { - promotion of a healthy } \\
\text { lifestyle, etc. }\end{array}$ & $\begin{array}{l}\text { - self-presentation and self- } \\
\text { promotion during education in order } \\
\text { to create a positive impression of } \\
\text { potential employers; } \\
\text { - successful internship, obtaining } \\
\text { recommendations for further } \\
\text { employment, etc. }\end{array}$ \\
\hline $\begin{array}{l}\text { Human capital } \\
\text { development }\end{array}$ & \multicolumn{3}{|c|}{$\begin{array}{l}\text { - attraction of investments for the development of human capital from the state, employers, international } \\
\text { organizations, public organizations, and non-state funds; } \\
\text { - establishment of values of comprehensive, harmonious human development in society, etc. }\end{array}$} \\
\hline The use of human capital & $\begin{array}{l}\text { - expansion of opportunities for } \\
\text { further training, acquisition of new } \\
\text { competencies during work activity; } \\
\text { - dual education; } \\
\text { - obtaining a second higher education, } \\
\text { etc. }\end{array}$ & $\begin{array}{l}\text { - expansion of opportunities } \\
\text { for the participation in } \\
\text { healthcare-saving measures; } \\
\text { - expansion of opportunities } \\
\text { for obtaining a better social } \\
\text { package, which provides } \\
\text { greater possibilities for saving } \\
\text { health, etc. }\end{array}$ & $\begin{array}{l}\text { - increase in the volume of providing } \\
\text { intermediary services in the labour } \\
\text { market (human resources agencies, } \\
\text { outsourcing companies, etc.); } \\
\text { - providing additional competitive } \\
\text { advantages in the labour market; } \\
\text { - socially responsible marketing of } \\
\text { employers in the labour market, etc. }\end{array}$ \\
\hline $\begin{array}{l}\text { Preservation of human } \\
\text { capital }\end{array}$ & $\begin{array}{l}\text { - establishing a culture of lifelong } \\
\text { learning; } \\
\text { - encouraging entrepreneurs to invest } \\
\text { in educational activities for the general } \\
\text { population, etc. }\end{array}$ & $\begin{array}{l}\text { - increased participation in } \\
\text { healthcare-saving measures; } \\
\text { - encouraging entrepreneurs } \\
\text { to invest in health-saving } \\
\text { measures, etc. }\end{array}$ & $\begin{array}{l}\text { - establishment of social and labour } \\
\text { values in society, the aspiration } \\
\text { to use existing human capital as } \\
\text { productively as possible; } \\
\text { - adaptation of workers to new forms } \\
\text { of labour organization, which are } \\
\text { changing under the influence of } \\
\text { information and communication } \\
\text { technologies, etc. }\end{array}$ \\
\hline
\end{tabular}

Note. Developed by the authors 
(as in other) processes requires, first and foremost, the most complete, transparent and honest information about the possibilities of dual education and further employment.

More efficient use of human capital will be facilitated by the use of marketing tools to improve the quality and increase the volume of mediation services in the labour market (human resources agencies, outsourcing companies, etc.), providing additional competitive advantages in the labour market, socially responsible marketing of employers in the labour market, etc. At the stage of preserving human capital, it is expedient to use marketing tools in order to establish social and labour values in society, use of available human capital as productively as possible, an adaptation of workers to new forms of labour organization, which are changing under the influence of information and communication technologies, etc.

It is necessary to emphasize the decisive role of the individual in the purposeful, effective, rational formation of his human capital. Indeed, people often fall victim to ill-fated information in education, healthcare, employment, especially when they are willing to obtain good at a low price, with little effort, bypassing moral norms, etc. But there are ways to check information, look at documents, ask the opinion of those who have already received such dubious services, that is, to force them to get true information. Not always consumers take responsibility, and therefore - often suffer from malicious marketing.

\section{Conclusions and prospects of further developments}

Currently, the processes of reproduction of human capital in Ukraine are strongly influenced by the processes of fiktivization, which are associated with the proliferation of its unproductive forms. In this context, the socially irresponsible marketing of educational and medical institutions, employers, and pharmaceutical and intermediary firms plays a significant role. An important factor in the privatization is also the reduction of social responsibility of employees in the formation of their human capital and the implementation of various measures of self-marketing.

Socially responsible marketing is impossible without the general spread of the ideology of social responsibility in society. The concept of social responsibility should become widespread in all spheres of public life; become a fundamental basis of social and labour relations and one of the most important directions of overcoming a systemic socio-economic, political, and military crisis in Ukraine.

It is necessary to strive and demand that the marketing information that promotes the competitiveness of the enterprise, organization or employee adequately reflects their objective characteristics and does not lead to the further diversification of the national human capital, the spread of false information, and the formation of a distorted perception of reality in a professional environment. The ideology of social responsibility should become the basis for the renewal of our society and the further development of the economy. It also implies the further development of continuous learning, in particular, the dual system, the spread of ideas of human development, rational consumption, the formation of a model of a healthy lifestyle, spiritual values in the whole society.

At the same time, citizens' awareness of personal responsibility for their own lives, health, education, and competitiveness in the labour market, in particular, rational consumption and conscious consumer choice, despite the seductive, dubious advertising, are essential.

Further research requires an assessment of the efficiency of human capital reproduction processes, taking into account the impact of activities of state authorities, enterprises, public organizations, and individual households on their progress; the question of the optimal choice of marketing tools at different stages of reproduction of human capital, as well as various aspects of reducing the process of fiktivization in the field of human capital.

\section{References:}

Agramakova, N. V. (2011). Suschnost sotsialnoy otvetstvennosti predpriyatiya i sistemyi ee regulirovaniya [The essence of corporate social responsibility and its control system]. Business Inform, no. 4, pp. 86-88.

Blagov, Yu. E. (2010). Korporativnaya sotsialnaya otvetstvennost: evolyutsiya kontseptsiy [Corporate social responsibility: evolution of concepts]. St. Petersburg: Vyisshaya shkola menedzhmenta. (in Russian)

Carroll, A. B. (1979). A Three-Dimensional Conceptual Model of Corporate Social Performance. Academy of Management Review, no. 4, pp. 497-505.

Hrishnova, O. A., Brintseva, O. G. (2015). Fiktyvnyi liudskyi kapital: sutnist, kharakterni osoblyvosti, chynnyky formuvannia [Fictitious human capital: essence, characteristics, formation factors]. Demography and social economy, vol. 1 (23), pp. 90-101.

Hrishnova, O. A. (2014). Liudskyi, intelektualnyi i sotsialnyi kapital Ukrainy: sutnist, vzaiemozviazok, otsinka, napriamy rozvytku [Human, intellectual and social capital of Ukraine: essence, interconnection, assessment, directions of development]. Social and Labour Relations: Theory and Practice, no. 1 (7), pp. 34-40.

Hrishnova, O. A., Mishchuk, H. Yu., Oliinyk, O. O. (2014). Sotsialna vidpovidalnist u trudovykh vidnosynakh: teoriia, praktyka, rehuliuvannia ryzykiv: Monohrafiia [Social responsibility in labour relations: theory, practice, risk management Monograph]. Rivne: NUVGP. (in Ukrainian) 
Kotler, P. (2008). Marketynh-menedzhment [Marketing Management]. St. Petersburg: Piter. (in Russian) Kotler, P. (1972). What Consumerism Means for Marketers. Harvard Business Review, vol. 50, pp. 48-57.

Lambin,J.-J. (1996). Strategicheskiy marketing. Evropeyskaya perspektiva [Strategic marketing. European perspective]. St. Petersburg: Nauka. (in Russian)

Lantos, J. P. (2002). The ethicality of altruistic corporate social responsibility. Journal of Consumer Marketing, vol. 19, no 3, pp. 205-232.

Libanova, E. M. (2014). Liudskyi rozvytok v Ukraini: istorychnyi vymir transformatsii derzhavnoi sotsialnoi polityky (kolektyvna monohrafiia) [Human development in Ukraine: the historical dimension of the transformation of government social policy (collective monograph)]. Kyiv: In-t demohrafii ta sots. doslidzh. Im. M.V. Ptukhy NAN Ukrainy. (in Ukrainian) 